\title{
III. Chemokines and Other Mediators, 8. Chemokines and Their Receptors in Cell-Mediated Immune Responses in the Lung
}

\author{
AKIHIRO MATSUKAWA, ${ }^{1}$ NICHOLAS W. LUKACS,${ }^{1}$ CORY M. HOGABOAM, ${ }^{1}$ STEPHEN W. CHENSUE, ${ }^{2}$ \\ AND STEVEN L. KUNKEL ${ }^{1 *}$ \\ ${ }^{1}$ Department of Pathology, University of Michigan Medical School, Ann Arbor, Michigan 48109 \\ ${ }^{2}$ Department of Pathology, Veteran Affairs Medical Center, Ann Arbor, Michigan 48105
}

\author{
KEY WORDS chemotactic cytokines; delayed hypersensitivity; Th1/Th2; cell-cell communica- \\ tion
}

\begin{abstract}
Chemokines constitute a large family of chemotactic cytokines that belong to a super-gene family of $8-10 \mathrm{kDa}$ proteins. The chemokines are considered to be primarily beneficial in host defense against invading pathogens. However, the reactions induced by chemokines can be occasionally excessive, resulting in a harmful response to the host. Recent studies in chemokine biology have elucidated that chemokines are involved in the initiation, development, and maintenance of numbers of diseases including lung diseases. In addition to its chemotactic activity, evidence suggests that chemokines can modify the outcome of the cell-mediated immune responses by altering the Th1/Th2 cytokine profile. Chemokines are also capable of dictating the direction of specific immune responses. Chemokine action is mediated by a large super-family of G-protein coupled receptors, and the receptors are preferentially expressed on Th1/Th2 cells. Certain chemokine receptors are constitutively expressed in immune surveying cells such as dendritic cells and naive $\mathrm{T}$ cells. The corresponding chemokines are present in normal lymphoid tissues, suggesting a role of chemokines/receptors in cell homing and cell-cell communication in lymphoid tissue that can be an initial step for immune recognition. Thus, comprehension of the chemokine biology in immune responses appears to be fundamental for understanding the pathogenesis of $\mathrm{T}$ cell-mediated immune responses. The following review will highlight the current insight into the role of chemokines and their receptors in the cell-mediated immune response, with a special focus on lung diseases. Microsc. Res. Tech. 53:298-306, 2001. @ 2001 Wiley-Liss, Inc.
\end{abstract}

\section{INTRODUCTION}

Due to a unique anatomical feature that achieves effective gas exchange, the lung is constantly exposed to the outer environment, which may allow a great variety of infectious microbes and small foreign particles to invade the lung. This can cause infection and inflammation, which may threaten host survival. However, the lung and respiratory tract are protected from invading pathogens by the host defense system (Roitt et al., 1998; Roussos, 1995). The nasal hair functions as a rough "filter." The Waldeyer's ring, a mucosa-associated lymphoid tissue complex at the entrance of the airway, reacts to pathogens that have entered via the surface barriers. The lining cells of the respiratory tract secrete mucus that traps small microbes and foreign particles, enabling the host to eject them from the respiratory tract. In the alveoli of the lung are the alveolar macrophages, which can ingest and destroy pathogens. Certain macrophages and dendritic cells carry processed antigens to adjacent draining lymph nodes, where the cells present antigens to naive T cells. The $\mathrm{T}$ cells release cytokines, that enable the phagocytes to destroy the pathogens that they have internalized. T cells also help B cells produce antibody that binds to pathogens and their products. The phagocytes then recognize the complex through Fc receptor bind- ing, allowing them to clear these pathogens. These adoptive immune responses are memorized and provide a more effective and rapid response when the host is re-infected with the same pathogens (Roitt et al., 1998; Roussos, 1995).

However, this normally beneficial immune response can occasionally cause an overwhelming inflammatory response and tissue damage when an adaptive immune response occurs in an exaggerated or inappropriate form. In granulomatous hypersensitivity reactions such as pulmonary tuberculosis, sarcoidosis, and hypersensitivity pneumonia, antigen-sensitized $\mathrm{T}$ cells traveling to the site of foci secrete excessive levels of cytokines, following a secondary contact with the same antigen. The cytokines activate macrophages, and activated macrophages amplify the inflammatory responses via releasing inflammatory mediators. These events can cause differentiation of macrophages to epithelioid cells and multinuclear giant cells, resulting in the formation of pulmonary granuloma (Agostini et al., 1998; Ando et al., 1999; Condos et al., 2000; Moller,

*Correspondence to: Dr. Steven L. Kunkel, Ph.D., Department of Pathology, University of Michigan Medical School, Med Sci I, Rm 5214, 1301 Catherine Rd., Ann Arbor, MI 48109. E-mail: slkunkel@umich.edu

Received 16 June 2000; accepted in revised form 25 June 2000 
1999). In allergic airway inflammation such as asthma, $\mathrm{T}$ cells secrete cytokines after antigen recognition, which include IL-4, IL-5, IL-10, and IL-13. These cytokines induce the production of antigen (allergen)-specific IgE from B cells. IgE enters the circulation and binds to mast cells throughout the body. Upon encountering the same allergen in the airway, the sensitized mast cells release inflammatory mediators inside the cells, which trigger a series of inflammatory cascades seen in asthma (Kay, 1998; Kon and Kay, 1999; Le Gros et al., 1998; also reviewed by Van Rijt and Lambrecht, pages 256-272, this issue). Recent studies have revealed that chemokines play an essential role in the initiation and maintenance of these types of lung diseases (Lukacs et al., 1999; Rothenberg, 2000; Rothenberg et al., 1999).

Historically, chemokines have been viewed as leukocyte chemoattractants that regulate cellular movement from the circulation into inflamed tissue (Baggiolini et al., 1997). However, as investigators continue to examine the function of chemokines in both disease and homeostatic circumstances, the identification of novel functions of chemokines in the regulation of immune responses has begun. Recent evidence suggests that certain chemokines and their receptors appear to be involved in dendritic cell and lymphocyte homing and cell-cell communication in lymphoid tissue (Allavena et al., 1999; Cyster, 1999). The recruitment, regulation, and activation of CD4+ T helper (Th) cells, and cytokine production from the cells may be the most critical issue in immune responses (Moser, 1998). It is now known that chemokine receptors have been found to be differentially associated with Th1/Th2 subsets (Sallusto et al., 1998a, 1999). Certain chemokine members are produced in infectious foci, allowing chemokines to traffic Th1/Th2 cells into inflamed sites (D'Ambrosio et al., 2000; Syrbe et al., 1999). Furthermore, CC chemokine members appear to alter the outcome of the immune responses through altering Th1/Th2 balance (Mantovani et al., 1998). Thus, chemokines and their receptors appear to affect the immune response at multiple levels.

\section{CHEMOKINES AND THEIR RECEPTORS}

A decade ago, two functional chemotactic cytokines with different activities were identified, which were designated IL-8 and MCP-1 (Yoshimura et al., 1987; 1989). After these initial discoveries, family members of chemotactic cytokines has been identified at a staggering pace through broad-based searches for sequence homology in EST databases. To date, over 50 members have been reported, and the number of chemokines is still growing (Baggiolini et al., 1997; Zlotnik and Yoshie, 2000). Chemokines belong to a super-gene family of 8-10 kDa basic heparin-binding proteins, and have been divided into 4 sub-families based upon their sequence homology and the position of cysteine residues in the proteins (Table 1). Two of these constitute quite a large number of chemokines, CC and CXC. CC chemokines attract monocytes, dendritic cells, eosinophils, or lymphocytes. CXC chemokines preferentially attract neutrophils, but some of them attract $\mathrm{T}$ or $\mathrm{B}$ cells. CXC chemokines can be divided into two subsets based on the presence or absence of specific amino acid residues Glu-Leu-Arg (ELR). CXC chemokines that contain the ELR motif are angiogenic factors, while non-ELR CXC chemokines that lack the ELR motif are angiostatic factors (Keane and Strieter, 1999). Recent evidence suggests that ELR-CXC chemokines, but not non-ELRCXC chemokines, are capable of inducing hepatocyte proliferation (Hogaboam et al., 1999b) as well as wound healing (Richmond et al., 1999). Very recently, lungkine, a novel ELR-CXC chemokine, has been identified, which is selectively expressed in lung epithelial cells, up-regulated in various lung inflammation models, and detected in fetal lung tissue. These activities suggest a role for this chemokine in lung-specific neutrophil trafficking as well as lung development (Rossi et al., 1999).

Chemokine receptors also constitute a subfamily of rhododopsin-like, 7 transmembrane, G protein-coupled receptors. To date, 18 chemokine receptors are known, and classified into 4 subtypes depending on which chemokine subfamily is recognized (Table 1). These chemokine receptors commonly bind multiple chemokines, although some of the chemokine receptors appear to bind a specific chemokine. Different receptors for the same chemokines can be co-expressed on the same cell type, even on the same cell (Murphy, 1997). The expression of a CC chemokine receptor (CCR) was believed to be restricted to cells that can respond to a specific CC chemokine. However, recent studies have shown that neutrophil can express CCR1, 2, and 3 under specific inflammatory conditions (Bonecchi et al., 1999; Johnston et al., 1999). Although CC chemokines were regarded to bind CCRs, a recent study has

Abbreviations

\begin{tabular}{llll} 
Cytokines: & & TARC & \multicolumn{1}{c}{ thymus and activation-regulated chemokine } \\
IFN & interferon & TECK & thymus-expressed chemokine \\
IL & interleukin & TCA & thymus-derived chemotactic agent \\
TGF & transforming growth factor & CXC chemokines: & B lymphocyte chemoattractant \\
CC chemokines: & BLC & B lymel \\
CTACK & cutaneous T cell-attracting chemokine & ENA & epithelial neutrophil activating protein \\
ECF & eosinophil chemotactic cytokine & GCP & granulocyte chemotactic protein \\
HCC & human CC chemokine & GRO & growth-related oncogene \\
LCC & liver-specific CC chemokine & IP & interferon- $\gamma$-inducible protein \\
MCP & monocyte chemoattractant protein & I-TAC & IFN-inducible T cell alpha chemoattractant \\
MDC & macrophage-derived chemokine & MIG & monokine induced by interferon- $\gamma$ \\
MIP & macrophage inflammatory protein & NAP & neutrophil activating protein \\
MPIF & myeloid progenitor inhibitory factor & PF & platelet factor \\
RANTES & regulated on activation, normal T expressed and se- & SDF & stromal cell-derived factor
\end{tabular}


TABLE 1. Chemokines and their sources, target cells and receptors

\begin{tabular}{|c|c|c|c|c|c|}
\hline Chemokines & $\begin{array}{l}\text { Prop } \\
\text { nomen }\end{array}$ & & Sources & Target cells & Receptors \\
\hline CC chemokines & & & & & \\
\hline TCA-3/I-309 & CCL1 & & $\mathrm{T}, \mathrm{MC}$ & $\mathrm{T}$ & CCR8 \\
\hline MCP-1/MCAF & CCL2 & & $\mathrm{M}, \mathrm{L}, \mathrm{F}, \mathrm{EC}, \mathrm{EP}, \mathrm{N}, \mathrm{MC}, \mathrm{G}, \mathrm{ME}$ & $\mathrm{M}, \mathrm{T}, \mathrm{NK}, \mathrm{DC}, \mathrm{N}$ & CCR2, 10, 11 \\
\hline MIP-1 $\alpha / L D 78 \alpha$ & CCL3 & & $\mathrm{M}, \mathrm{L}, \mathrm{N}, \mathrm{E}, \mathrm{F}, \mathrm{MC}, \mathrm{BA}, \mathrm{NK}$ & M, T, NK, E, DC, & CCR 1,5 \\
\hline MIP-1 $\beta /$ Act-2/HC21 & CCL4 & & $\mathrm{M}, \mathrm{L}, \mathrm{N}, \mathrm{F}, \mathrm{MC}$ & $\mathrm{M}, \mathrm{T}, \mathrm{NK}, \mathrm{DC}$ & CCR5, 8 \\
\hline RANTES & CCL5 & & $\mathrm{T}, \mathrm{M}, \mathrm{F}, \mathrm{ME}$ & $\begin{array}{l}\mathrm{T}, \mathrm{E}, \mathrm{NK}, \mathrm{BA}, \\
\mathrm{NK}\end{array}$ & CCR $1,3,5,11$ \\
\hline C10/MPR-1 (murine) & CCL6 & & M, E, microglia & $\mathrm{M}$ & $?$ \\
\hline MCP-3 & CCL7 & & $\mathrm{P}, \mathrm{M}, \mathrm{MC}, \mathrm{F}$ & $\begin{array}{l}\text { M, T, NK, DC, E, } \\
\text { SM, BA }\end{array}$ & CCR $1,2,3,10,11$ \\
\hline MCP-2 & CCL8 & & $\mathrm{M}, \mathrm{F}$ & $\begin{array}{l}\text { M, T, NK, DC, E, } \\
\text { SM, BA }\end{array}$ & CCR2, 3, 11 \\
\hline MIP-1 $\gamma / \mathrm{MPR}-2 / \mathrm{CCF}-18$ (murine) & CCL9/10 & & $\begin{array}{l}\text { M, DC, liver, thymus, lung, } \\
\text { pancreas }\end{array}$ & $\mathrm{DC}, \mathrm{T}$ & CCR1 \\
\hline Eotaxin-1 & CCL11 & & $\mathrm{EC}, \mathrm{EP}, \mathrm{E}$, lung & $\mathrm{E}, \mathrm{BA}$ & CCR3 \\
\hline MCP-5 (murine) & CCL12 & & M, lymph node & $\mathrm{M}, \mathrm{E}$ & CCR2 \\
\hline MCP- $4 / \mathrm{CK} \beta 10$ & CCL13 & & DC, thymus, lung, colon, intestine & $\mathrm{M}, \mathrm{T}, \mathrm{E}, \mathrm{BA}$ & CCR2, 3, 11 \\
\hline HCC-1 & CCL14 & & $\begin{array}{l}\text { bone marrow, spleen, liver, gut, } \\
\text { SM }\end{array}$ & $\begin{array}{l}\text { M, myeloid } \\
\text { progenitor }\end{array}$ & CCR1 \\
\hline HCC-2/MIP-18/LKN-1/MIP-5 & CCL15 & & $\mathrm{DC}, \mathrm{M}, \mathrm{T}, \mathrm{B}$ & $\mathrm{M}, \mathrm{T}$ & CCR1 \\
\hline HCC-4/LEC/NCC-4/LMC & CCL16 & & M & $\mathrm{M}$ & $?$ \\
\hline TARC & CCL17 & & DC, M, Reed-Sternberg cell & DC, Th2 & $\mathrm{CCR} 4,8$ \\
\hline MIP-4/PARC/DC-CK1/AMAC-1 & CCL18 & & $\mathrm{DC}, \mathrm{M}$ & $\mathrm{T}$ & $?$ \\
\hline MIP-3 $\beta / E L C / E x o d u s-3$ & CCL19 & & $\begin{array}{l}\text { thymus, lymph node, appendix, } \\
\text { spleen, gut }\end{array}$ & $\mathrm{T}, \mathrm{B}, \mathrm{NK}$ & CCR7 \\
\hline MIP-3 $\alpha /$ LARC/Exodus- 1 & CCL20 & & $\begin{array}{l}\text { M, T, liver, lung, thymus, placenta, } \\
\text { appendix }\end{array}$ & $\mathrm{DC}, \mathrm{T}, \mathrm{NK}$ & CCR6 \\
\hline 6Ckin/SLC/TCA-4/Exodus-2/CK $\beta 9$ & & & stromal cells in lymph node, EC & $\mathrm{T}, \mathrm{NK}$ & CCR7 \\
\hline MDC/STCP-1/ABCD-1 & CCL22 & & DC, M, B, T, EP (thymus) & DC, Th2, NK & CCR4 \\
\hline MPIF-1/CK $\beta 8$ & CCL23 & & $\mathrm{DC}, \mathrm{M}$, lung, liver & $\mathrm{M}, \mathrm{T}$ & CCR1 \\
\hline Eotaxin-2/MPIF-2/CK $\beta 6$ & CCL24 & & M, T, lung, liver, spleen, thymus & $\mathrm{E}, \mathrm{BA}$ & CCR3 \\
\hline TECK & CCL25 & & $\mathrm{DC}, \mathrm{EC}$, gut & $\mathrm{T}$, thymocyte & CCR9 \\
\hline Eotaxin-3 & CCL26 & & EC, heart, ovary & $\mathrm{E}, \mathrm{BA}$ & CCR3 \\
\hline CTACK/ILC, ESkine (murine) & CCR27 & & skin, placenta & $\mathrm{T}$ & CCR10 \\
\hline LCC-1 & & & liver & $?$ & ? \\
\hline ECF-L & & & spleen, bone marrow, lung, heart & $\mathrm{E}$ & $?$ \\
\hline CXC Chemokines & ELR & & & & \\
\hline GRO $\alpha / M G S A-\alpha$ & CXCL1 & + & M, N, EC, F, melanoma cell & $\mathrm{N}, \mathrm{MC}$ & $\mathrm{CXCR} 2>\mathrm{R} 1$ \\
\hline GRO $\beta /$ MGSA- $\beta$ & CXCL2 & + & $\mathrm{M}, \mathrm{N}, \mathrm{EC}, \mathrm{F}$, melanoma cell & $\mathrm{N}$ & CXCR2 \\
\hline GRO $\gamma / \mathrm{MGSA}-\gamma$ & CXCL3 & + & $\mathrm{M}, \mathrm{N}, \mathrm{EC}, \mathrm{F}$, melanoma cell & $\mathrm{N}$ & CXCR2 \\
\hline $\mathrm{PF} 4$ & CXCL4 & - & $\mathrm{P}$, megakariocyte & M, EC & ? \\
\hline ENA-78 & CXCL5 & + & $\mathrm{EC}, \mathrm{P}$ & $\mathrm{N}, \mathrm{MC}$ & CXCR2 \\
\hline GCP-2 & CXCL6 & + & $\mathrm{EC}$, osteosarcoma cell & $\mathrm{N}$ & CXCR1, 2 \\
\hline NAP-2/CTAP-III & CXCL7 & + & $\mathrm{P}, \mathrm{EC}$ & $\mathrm{N}, \mathrm{MC}$ & CXCR2 \\
\hline IL-8/NAP-1/MDNCF & CXCL8 & + & $\begin{array}{l}\text { M, T, F, K, H, EP, EC, N, P, AS, } \\
\quad \text { G, ME, BA, NK }\end{array}$ & $\mathrm{N}, \mathrm{MC}, \mathrm{E}, \mathrm{NK}$ & CXCR1, 2 \\
\hline MIG & CXCL9 & - & $\mathrm{M}, \mathrm{N}$ & $\mathrm{T}, \mathrm{NK}, \mathrm{EC}$ & CXCR3 \\
\hline IP-10/CRG-2 & CXCL10 & - & $\mathrm{M}, \mathrm{K}, \mathrm{N}, \mathrm{F}, \mathrm{EC}, \mathrm{AS}, \mathrm{G}$ & $\mathrm{T}, \mathrm{NK}, \mathrm{EC}$ & CXCR3 \\
\hline I-TAC/beta-R1/H174/IP-9 & CXCL11 & & $\mathrm{AS}, \mathrm{M}, \mathrm{N}$ & $\mathrm{T}, \mathrm{NK}$ & CXCR3 \\
\hline SDF-1/PBSF & CXCL12 & - & stromal cell & $\mathrm{T}, \mathrm{M}, \mathrm{DC}, \mathrm{NK}$ & CXCR4 \\
\hline BLC/BCA-1 & CXCL13 & - & spleen, lymph node & $\mathrm{B}, \mathrm{T}, \mathrm{M}$ & CXCR5 \\
\hline BRAK/bolekine & CXCL14 & - & & & $?$ \\
\hline Lungkine (murine) & & + & EC (lung) & $\mathrm{N}$ & $?$ \\
\hline C Chemokine & & & & & \\
\hline Lymphotactin- $\alpha / \mathrm{SCM}-1 \alpha$ & XCL1 & & $\mathrm{T}, \mathrm{NK}$ & $\mathrm{T}, \mathrm{NK}$ & XCR1 \\
\hline Lymphotactin- $\beta /$ SCM-1 $\beta$ & XCL2 & & $\mathrm{T}, \mathrm{NK}$ & $\mathrm{T}$ & XCR1 \\
\hline CX3C Chemokine & & & & & \\
\hline Fractalkine/Neurotactin & CX3CL1 & & $\mathrm{EC}, \mathrm{DC}, \mathrm{T}$, brain & $\mathrm{M}, \mathrm{DC}, \mathrm{T}, \mathrm{NK}$ & CX3CR1 \\
\hline
\end{tabular}

Cell abbreviations: AS, astrocyte; B, B cell; BA, basophil; DC, dendritic cell; EC, endothelial cell; EP, epithelial cell; E, eosinophil; F, fibroblast; G, glioblastoma; H, hepatocyte; K, keratinocyte; L, lymphocyte; M, monocyte/macrophage; MC, mast cell; ME, mesangial cell; N, neutrophil; P, platelet; SM, smooth muscle cell; T, T cell. The nomenclature was proposed by Drs. O. Yoshie and A. Zlotnik (Immunity, 12, 121-127, 2000).

revealed that $\mathrm{CC}$ chemokine 6Ckine binds the $\mathrm{CXC}$ chemokine receptor CXCR3 (Soto et al., 1998). Thus, receptor expression and its recognition by chemokines appear to be more complicated than anticipated. It is possible that the overlapping receptor recognition by chemokines may be important for inducing an efficient signal transduction or may function as a back-up system.

\section{CHEMOKINES AS CENTRAL MEDIATORS OF CELL-CELL COMMUNICATION IN LYMPHOID TISSUE}

The antigen presentation to $\mathrm{T}$ cells is the initial step for the immune response. In this regard, dendritic cells (DC) play a crucial role as a sentinel of the adoptive 
TABLE 2. Preferential expression of chemokine receptors on Th1/Th2 cells

\begin{tabular}{lll}
\hline $\begin{array}{l}\text { Th1/Th2 } \\
\text { cells }\end{array}$ & Receptors & \multicolumn{1}{c}{ Chemokines } \\
\hline Th1 cells & CCR5 & MIP-1 $\alpha,-\beta$, RANTES \\
& CXCR3 & MIG, IP-10, I-TAC \\
Th2 cells & CCR3 & RANTES, MCP-2, -3, -4, Eotaxin-1, -2, -3 \\
& CCR4 & TARC, MDC \\
& CCR8 & TCA-3, MIP-1 $\beta$, TARC \\
\hline
\end{tabular}

immune system (Ludewig et al., 1999). Immature DCs, which localize in non-lymphoid tissue, capture and process antigens. Upon stimulation, DCs travel to adjacent lymphoid tissue and present the processed antigen to naive T cells. Chemokines and their receptors appear to be involved in this cell movement and trafficking (Cyster, 1999). Immature DCs respond to an array of CC and CXC chemokines including MIP-1 $\alpha$, MIP-1 $\beta$, MIP-1 $\gamma$, MIP-3 $\alpha$, MCP-1, MCP-2, MCP-3, MCP-4, TARC, MDC, SDF-1, and Fractalkine (Table 1). The most potent chemoattractant of DCs is MIP-3 $\alpha$, and the receptor CCR6 is expressed on immature DCs. Upon stimulation, the CCR6 expression is shown to be downregulated, whereas CCR7 expression is upregulated (Dieu et al., 1998). MIP-3 $\alpha$ is present only in inflamed site, while CCR7 ligand 6Ckine is expressed by high endothelial venules (HEVs) in lymphoid tissue. 6Ckine and another CCR7 ligand MIP-3 $\beta$ are also expressed in the T cell area of lymphoid tissue (Dieu et al., 1998), suggesting a role of CCR7 and its ligands in DC trafficking into lymphoid tissue (Saeki et al., 1999). Correspondingly, CCR7 knockout mice showed decreased migration of DCs into the T cell area (Forster et al., 1999; Gunn et al., 1999). Mature DCs secrete T cell chemoattractants, such as MIP-3 $\beta$ (Dieu et al., 1998; Ngo et al., 1998) and MIP-4 (Adema et al., 1997; Guan et al., 1999), probably enabling naive $T$ cells to scan efficiently for antigen that is presented by DCs. When naive $\mathrm{T}$ cells are activated, the $\mathrm{T}$ cells undergo a transient switch in receptor expression, depending on the Th1/Th2 polarization (Sallusto et al., 1999). The activated $\mathrm{T}$ cells may decrease CCR7 expression and upregulate CXCR5 expression, and become responsive to BLC, while at the same time losing response to 6Ckine and MIP-3 $\beta$ (Ansel et al., 1999; Walker et al., 1999), probably allowing $\mathrm{T}$ cells to encounter B cells. CXCR5 is also expressed on B cells, and BLC-CXCR5 interaction is essential for follicle formation, as migration of lymphocytes into the follicles is impaired in CXCR5 deficient mice (Forster et al., 1996). These findings suggest that chemokines and their receptors are essential for the immune recognition that is an initial step for immune responses.

\section{DIFFERENTIAL EXPRESSION OF CHEMOKINES RECEPTORS ON Th1/Th2 CELLS}

It is well known that CD4+ T helper (Th) cells have two subsets based on the profile of cytokine production. Th1 cells are characterized by the production of IFN $\gamma$, IL-2, and IL-12, whereas Th2 cells are typified by the production of IL-4, IL-5, IL-10, and IL-13. Cytokines produced from Th1 cells inhibit the actions of Th2 cells, and vice versa (Romagnani, 1997). The selective differentiation of either subset is established during priming, depending on their antigenic experience and a variety of surrounding factors (Constant and Bottomly, 1997). Recent in vitro data using polarized human Tcell lines suggest that chemokine receptors are preferentially expressed on Th1/Th2 cells, as part of the cell differentiation (Table 2). CCR5 and CXCR3 are preferentially found on Th1 cells, whereas CCR3, CCR4, and CCR8 are on Th2 cells (Bonecchi et al., 1998; D'Ambrosio et al., 1998; Sallusto et al., 1998b; Imai et al., 1999). It is thus conceivable that Th1/Th2 cells selectively migrate in response to the corresponding chemokines, which can be produced at the sites (Baggiolini, 1998; Sallusto et al., 1999; Zlotnik et al., 1999). Th1/Th2 cells produce sets of chemokines, including MIP- $1 \alpha$, MIP-1 $\beta$, RANTES, MDC, TARC, and TCA-3, which may amplify the recruitment of Th1/Th2 cells at sites of antigenic recognition. Recent clinical studies have shown the existence of flexible programs of chemokine receptor expression during the development of diseases. CCR5 was found on memory $\mathrm{T}$ cells from Crohn's disease, a Th1-dominated disorder, whereas CCR3 was found on the cells from systemic sclerosis, a Th2-dominant disorder (Annunziato et al., 1999). Likewise, an elevated serum level of MDC was detected in patients with mycosis fungoides/Sezary syndrome or atopic dermatitis, a Th2-dominant disorder (Galli et al., 2000). Animal studies have shown that chemokines play an essential role in attracting Th1/Th2 cells to inflammatory sites, depending on the Th1/Th2 polarization (Yoneyama et al., 1998; Vestergaard et al., 1999; Lloyd et al., 2000). Evidence from recent studies also suggest that CCR1 and CCR2 may play an important role in tissue-specific localization of Th1 and Th2 cells, respectively, as Th1-type cytokine up-regulated the expression of CCR1 while inhibiting CCR2 (PentonRol et al., 1998; Bonecchi et al., 1999; Colantonio et al., 1999).

\section{CHEMOKINES IN Th1/Th2-CELL MEDIATED PULMONARY GRANULOMA}

As discussed above, the Th1/Th2 paradigm appears to direct the feature of immune responses, and the recruitment of Th1/Th2 cells is likely to be regulated by chemokines. In the context of T cell-mediated pulmonary disease, models have been established that predominantly exhibit either a Th1- or Th2-type cytokine profile (Kunkel et al., 1996, 1998). Mice sensitized with purified protein derivative (PPD) from Mycobacteria bovis or Schistosoma mansoni eggs challenged with beads coated with PPD or Schistosoma egg antigen (SEA) develop a granuloma formation that is associated with the production of either Th1 or Th2-cytokine, respectively (Chensue et al., 1994a,b; Henderson et al., 1991, 1992). The importance of Th1/Th2 cytokines in the development of the granuloma formation has been confirmed by using antibodies against Th1/Th2 cytokines and gene technology (Chensue et al., 1992, 1995a,c, 1997a,b; Fallon et al., 2000; Lukacs et al., 1997a). Thus, specific cytokine phenotype apparently dictates the progression of cell-mediated pulmonary immune response.

Histologically, the Th1-type granuloma typically consists of macrophages and lymphocytes, whereas the 


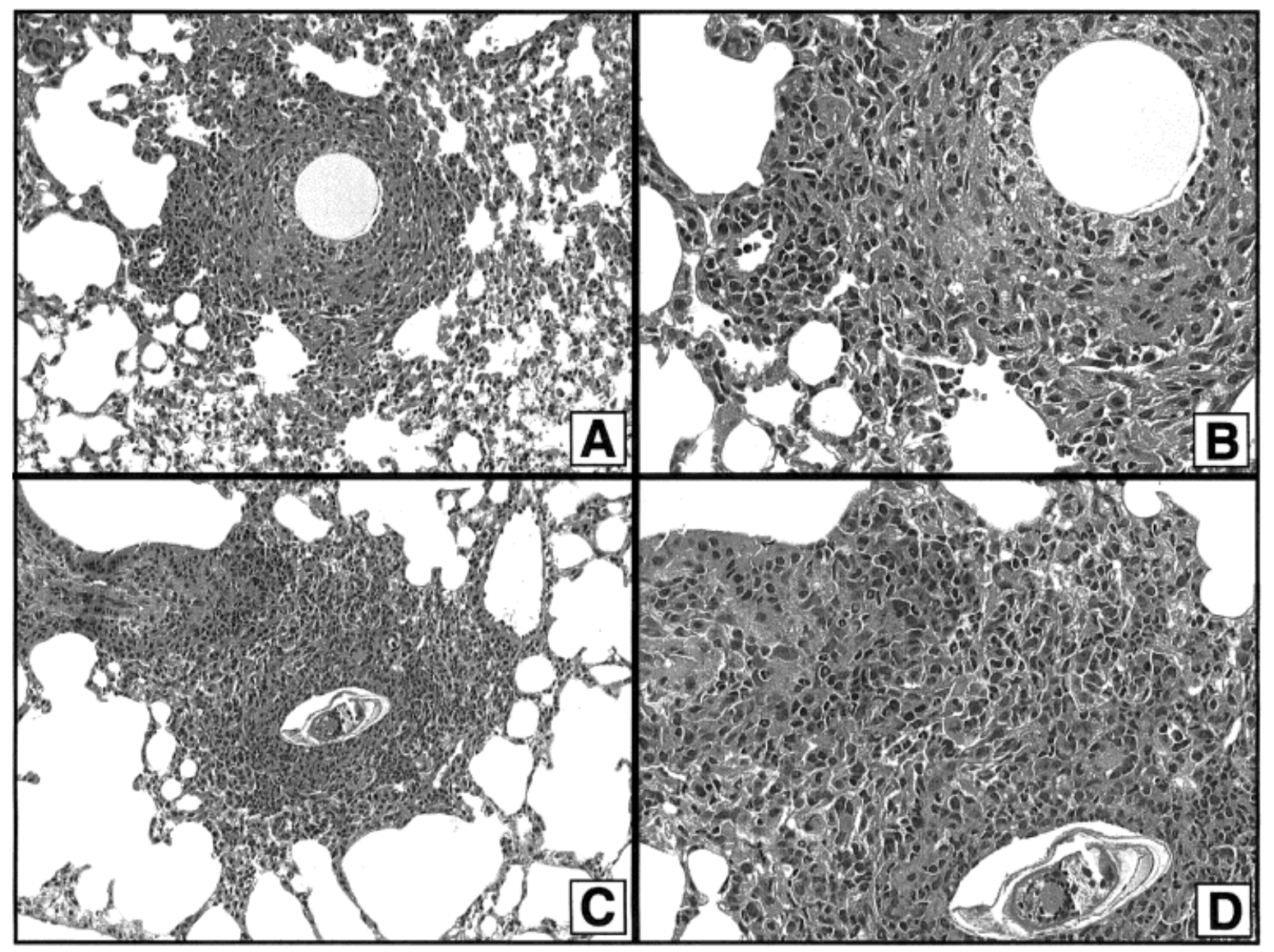

Fig. 1. Histology of experimental models of pulmonary granuloma. Mice were sensitized to PPD from Mycobacteria or Schistosoma mansoni egg and were challenged i.v. with PPD (Th1-type) or Schistosoma mansoni egg (Th2-type). The photos are representative of Th1-type (A,B) and Th2-type (C,D) granuloma models (H\&E staining). Magnification: A and C, $\times 200$; B and D, $\times 400$.

Th2-type granuloma contains mononuclear cells and eosinophils (Fig. 1), suggesting that different chemokines are likely to be involved in the development of the granuloma formation. Recent studies have begun to provide insight into the mechanism(s) whereby chemokines, especially CC chemokines, play an essential role in the granuloma formation in experimental models. $\mathrm{CC}$ chemokine production in the lung has been preferentially observed between the models. The level of RANTES in Th1-type granuloma was greater than that in Th2-type granuloma (Chensue et al., 1999), while higher levels of MCP-1 (Chensue et al., 1996; Hogaboam et al., 1999a) and eotaxin (Ruth, 1998) were detected in Th2-granuloma. Consistently, the expression of CCR2 and CCR3, a receptor for MCP-1 and eotaxin, respectively, is preferentially up-regulated in Th2-granuloma (Ruth et al., 1998; Hogaboam et al., 1999a). Evidence from neutralizing studies using antibodies against specific chemokines and from mice with specific disrupted chemokines/receptors gene has allowed us to understand the involvement of chemokines in the evolution of granuloma formation. Table 3 summarizes the current results of the studies addressing the role of chemokines in these models. The data suggest that MCP-1 contributes more to the Th2-type granuloma than Th1-type granuloma, as mice treated with anti-MCP-1 antibodies and mice deficient in MCP-1 gene showed reduced granuloma formation in the Th1-type model whereas no change was observed in the Th1-type model after anti-MCP-1 treatment (Chensue et al., 1995b, 1996; Lu et al., 1998). Correspondingly, CCR2 deficient mice showed a decreased size of granuloma in the Th2-type model (Warmington et al., 1999). Interestingly, IL-4 production was decreased in these studies, and, in turn, IL-4 blockade in mice developing Th2-type granuloma reduced the production of MCP-1 (Chensue et al., 1996). Thus, an immunoregulatory role of MCP-1/CCR2 appears to be related, in part, to the development of Th2-type granuloma. In the Th1-type model, neutralization of MCP-1 did not inhibit the granuloma formation while CCR2 -/- mice showed a smaller granuloma than wild-type, which was associated with decreases in the level of IFN $\gamma$ and IL-2 (Boring et al., 1997; Chensue et al., 1996). The data suggest that chemokines other than MCP-1 that can bind CCR2 (i.e., MCP-2, MCP-3, MCP-4, and MCP-5) may be involved in the progression of Th1-type granuloma. MIP-1 $\alpha$ and RANTES appear to be preferentially involved in the development of Th1-type granuloma. MIP-1 $\alpha$ deficient mice developed a smaller 
TABLE 3. Chemokines and their receptors in the development of Th1-and Th2-type pulmonary granuloma models ${ }^{1}$

\begin{tabular}{|c|c|c|c|c|}
\hline $\begin{array}{l}\text { Targetting } \\
\text { chemokines }\end{array}$ & Depletion $^{2}$ & $\begin{array}{l}\text { Granuloma size } \\
\quad \text { (vs. control) }\end{array}$ & Th1/Th2 cytokine profile & References \\
\hline \multicolumn{5}{|c|}{ Th1-type granuloma } \\
\hline MCP-1 & Antibodies & No change & No change & Chensue et al. (1996) \\
\hline MIP- $1 \alpha$ & Gene knockout & $\downarrow$ & Decreased IFN $\gamma / \mathrm{IL}-2$, increased IL-4/IL-5 & Hogaboam et al. (1999c) \\
\hline RANTES & Antibodies & $\downarrow$ & No change & Chensue et al. (1999) \\
\hline Eotaxin & Antibodies & $\downarrow$ & Decreased IFNy & Ruth et al. (1997) \\
\hline CCR2 & Gene knockout & $\downarrow$ & Decreased IFN $\gamma / \mathrm{IL}-2$ & Boring et al. (1997) \\
\hline \multicolumn{5}{|c|}{ Th2-type granuloma } \\
\hline MCP-1 & Antibodies & $\downarrow$ & Decreased IL-4/IL-5 & Chensue et al. (1995b, 1996) \\
\hline & Gene knockout & $\downarrow$ & Decreased IL-4/IL-5 & Lu et al. (1998) \\
\hline MIP-1 $\alpha$ & Gene knockout & No change & Decreased IL-4/IL-5 & Hogaboam et al. (1999c) \\
\hline RANTES & Antibodies & $\uparrow$ & Decreased IL-4/IL-5/IL-10/IL-13 & Chensue et al. (1999) \\
\hline Eotaxin & Antibodies & 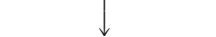 & Decreased IL-5 & Ruth et al. (1997) \\
\hline CCR1 & Gene knockout & $\downarrow$ & Decreased IL-4, increased IFN $\gamma$ & Gao et al. (1997) \\
\hline CCR2 & Gene knockout & $\downarrow$ & Decreased IL-4 & Warmington et al. (1999) \\
\hline
\end{tabular}

${ }^{1}$ Mice were sensitized to PPD from Mycobacteria or Schistosoma mansoni egg and were challenged i.v. with PPD (Th1-type) or SEA (Th2-type). Granuloma size was measured by lung sections. Cytokines were measured in the lung or draining lymph nodes.

${ }^{2}$ Results were obtained from mice using neutralizing antibodies against specific antibodies, or mice desrupted chemokine/receptor gene.

granuloma than the wild-type which was associated with decreased IFN $\gamma$ and IL-2, and in contrast, increased IL-4/IL-5, whereas no change was found in the Th2-type granuloma although the level of IL-4 and IL-5 was decreased (Hogaboam et al., 1999c). MIP-1 $\alpha$ is shown to enhance the production of IFN $\gamma$ by activated T cells (Karpus et al., 1997). RANTES blockade decreased the granuloma size in the Th1-type model, while increasing the Th2-type lesion that was accompanied by the increase in the level of IL-4, IL-5, IL-10, and IL-13 (Chensue et al., 1999). Convincingly, infusion of RANTES reduced the Th2-type lesion, but not the Th1-type lesion, and augmented type 1 and impaired type 2 responses in the lymph nodes. In vitro, RANTES caused selective, dose-related inhibition of IL-4 that was largely dependent on ligation of CCR1 receptors (Chensue et al., 1999). CCR1 deficient mice, the receptor for MIP-1 $\alpha$ and RANTES, showed decreased granuloma formation in the Th2-type model, which was associated with the decreased level of IL-4 while increasing IFNy (Gao et al., 1997). Neutralization of eotaxin decreased the IFN $\gamma$ level in regional lymph nodes and granuloma size in Th1-type model, as well as reduced the IL-5 level and granuloma size in the Th2-type model (Ruth et al., 1998). All these findings suggest that chemokines/receptors influence the granuloma formation not only through direct effects on leukocyte chemotaxis, but also through altering the Th1/Th2 cytokine balance.

\section{CHEMOKINES DIRECT THE IMMUNE RESPONSE}

In addition to altering the Th1/Th2 cytokine balance in the evolution of immune responses, chemokines apparently direct the immune system toward a specific response. In particular, CC chemokines are capable of regulating $\mathrm{T}$ cell activation and function during specific immune responses. Earlier studies have demonstrated that RANTES can directly activate $\mathrm{T}$ cells in vitro, specifically activating relevant signal transduction pathways (Bacon et al., 1995, 1996). Other evidence suggests that CC chemokines, such as MIP-1 $\alpha$, MIP$1 \beta$, RANTES, and MCP-1 enhance adjuvant activity and increase $\mathrm{T}$ cell activation and IL- 2 production
(Taub et al., 1996a,b). MCP-1 is shown to inhibit the production of IL-12 in peritoneal macrophages (Chensue et al., 1996). MCP-1 can induce the production of suppressive cytokines TGF $\beta$ that may impact on the production of Th1 type responses, such as IL-12 production (Gharaee-Kermani et al., 1996). Chemokines may also influence the differentiation of native $\mathrm{T}$ cells to Th1 or Th2 cells, as MCP-1 contributes to the production of IL-4 from antigen activated T cells, while MIP-1 $\alpha$ enhances IFN $\gamma$ production (Karpus et al., 1997; Lukacs et al., 1997b; Hogaboam et al., 1998). In vivo, MCP-1 regulates oral tolerance in the development of experimental autoimmune encephalomyelitis through the regulation of IL-12 production as well as antigen-specific Th1 cell responses (Karpus et al., 1998). MCP-1 attenuates the severity of septic response via decreasing the production of IL-12, IFN $\gamma$, and $\mathrm{TNF}_{\alpha}$ (Matsukawa et al., 2000a; Zisman et al., 1997). Interestingly, MCP-1 transgenic mice failed to clear bacteria, possibly reflecting an altered ability to generate the Th1 immune response (Rutledge et al., 1995). Our recent data in pulmonary granuloma models have shown that the over-expression of MCP-1 at specific phases of the developing responses appears to differentially alter the outcome of the immune responses (Matsukawa et al., 2000b). When MCP-1 was over-expressed at the beginning of the immune response at a time when $\mathrm{T}$ cells would first be in contact with antigen, a decreased size of granuloma was observed in the Th1-type model while increasing the Th2type granuloma. The regulation of Th1/Th2-type cytokine by MCP-1 is likely the mechanism, as activated T cells recovered from MCP-1 treated mice showed decreased production of IFN $\gamma$ and IL-12 in the Th1-type model, and, in contrast, increased production of IL-10 and IL-13 in the Th2-type model. When MCP-1 was over-expressed during the elicitation phase of the responses, neither the Th1-type nor the Th2-type granuloma was altered, suggesting that the function of MCP-1 may depend upon the stage and type of immune response (Matsukawa et al., 2000b). Thus, chemokines, in particular MCP-1, appear to have multiple effects on a developing immune response and influence the direction of an immune response. 


\section{CONCLUDING REMARKS}

In addition to its original chemotactic activity toward specific types of cell populations, chemokines have a broad spectrum of activities ranging from immune cell homing and immune recognition in lymphoid tissue to the regulation of immune responses against specific antigens. Therefore, chemokines aid in determining the direction and intensity of the acquired immune responses. Chemokines are also well known to govern innate immunity (Mahalingam and Karupiah, 1999). Innate immune responses are tightly linked to acquired immune responses, suggesting that chemokines may play a key role in connecting these immune responses. There is little doubt that a further understanding of the chemokine biology will shed light on the therapeutic approach for the treatment of refractory pulmonary diseases.

\section{REFERENCES}

Adema GJ, Hartgers F, Verstraten R, de Vries E, Marland G, Menon S, Foster J, Xu Y, Nooyen P, McClanahan T, Bacon KB, Figdor CG. 1997. A dendritic-cell-derived C-C chemokine that preferentially attracts naive T cells. Nature 387:713-717.

Agostini C, Perin A, Semenzato G. 1998. Cell apoptosis and granulomatous lung diseases. Curr Opin Pulm Med 4:261-266.

Allavena P, Luini W, Bonecchi R, D'Amico G, Bianchi G, Longoni D, Vecchi A, Mantovani A, Sozzani S. 1999. Chemokines and chemokine receptors in the regulation of dendritic cell trafficking. Chem Immunol 72:69-85.

Ando M, Suga M, Kohrogi H. 1999. A new look at hypersensitivity pneumonitis. Curr Opin Pulm Med 5:299-304.

Annunziato F, Cosmi L, Galli G, Beltrame C, Romagnani P, Manetti R, Romagnani S, Maggi E. 1999. Assessment of chemokine receptor expression by human Th1 and Th2 cells in vitro and in vivo. J Leukoc Biol 65:691-699.

Ansel KM, McHeyzer-Williams LJ, Ngo VN, McHeyzer-Williams MG, Cyster JG. 1999. In vivo-activated CD4 T cells upregulate CXC chemokine receptor 5 and reprogram their response to lymphoid chemokines. J Exp Med 190:1123-1134.

Bacon KB, Premack BA, Gardner P, Schall TJ. 1995. Activation of dual T cell signaling pathways by the chemokine RANTES. Science 269:1727-1730

Bacon KB, Szabo MC, Yssel H, Bolen JB, Schall TJ. 1996. RANTES induces tyrosine kinase activity of stably complexed p125FAK and ZAP-70 in human T cells. J Exp Med 184:873-882.

Baggiolini M. 1998. Chemokines and leukocyte traffic. Nature 392: 565-568.

Baggiolini M, Dewald B, Moser B. 1997. Human chemokines: an update. Annu Rev Immunol 15:675-705.

Bonecchi R, Bianchi G, Bordignon PP, D'Ambrosio D, Lang R, Borsatti A, Sozzani S, Allavena P, Gray PA, Mantovani A, Sinigaglia F. 1998. Differential expression of chemokine receptors and chemotactic responsiveness of type $1 \mathrm{~T}$ helper cells (Th1s) and Th2s. J Exp Med 187:129-134.

Bonecchi R, Polentarutti N, Luini W, Borsatti A, Bernasconi S, Locati M, Power C, Proudfoot A, Wells TN, Mackay C, Mantovani A, Sozzani S. 1999. Up-regulation of CCR1 and CCR3 and induction of chemotaxis to CC chemokines by IFN-gamma in human neutrophils. J Immunol 162:474-479

Boring L, Gosling J, Chensue SW, Kunkel SL, Farese RV Jr, Broxmeyer HE, Charo IF. 1997. Impaired monocyte migration and reduced type 1 (Th1) cytokine responses in C-C chemokine receptor 2 knockout mice. J Clin Invest 100:2552-2561.

Chensue SW, Terebuh PD, Warmington KS, Hershey SD, Evanoff HL, Kunkel SL, Higashi GI. 1992. Role of IL-4 and IFN-gamma in Schistosoma mansoni egg-induced hypersensitivity granuloma formation. Orchestration, relative contribution, and relationship to macrophage function. J Immunol 148:900-906.

Chensue SW, Warmington K, Ruth J, Lincoln P, Kuo MC, Kunkel SL. 1994a. Cytokine responses during mycobacterial and schistosomal antigen-induced pulmonary granuloma formation. Production of Th1 and Th2 cytokines and relative contribution of tumor necrosis factor. Am J Pathol 145:1105-1113.

Chensue SW, Warmington KS, Ruth J, Lincoln PM, Kunkel SL. 1994b. Cross-regulatory role of interferon-gamma (IFN-gamma), IL-4 and IL-10 in schistosome egg granuloma formation: in vivo regulation of Th activity and inflammation. Clin Exp Immunol 98:395-400.

Chensue SW, Ruth JH, Warmington K, Lincoln P, Kunkel SL. 1995a. In vivo regulation of macrophage IL-12 production during type 1 and type 2 cytokine-mediated granuloma formation. J Immunol 155:3546-3551.

Chensue SW, Warmington KS, Lukacs NW, Lincoln PM, Burdick MD, Strieter RM, Kunkel SL. 1995b. Monocyte chemotactic protein expression during schistosome egg granuloma formation. Sequence of production, localization, contribution, and regulation. Am J Pathol 146:130-138

Chensue SW, Warmington KS, Ruth JH, Lincoln P, Kunkel SL. 1995c. Cytokine function during mycobacterial and shicstosomal antigeninduced pulmonary granuloma formation. Local and regional participation of IFN-gamma, IL-10, and TNF. J Immunol 154:59695976.

Chensue SW, Warmington KS, Ruth JH, Sanghi PS, Lincoln P, Kunkel SL. 1996. Role of monocyte chemoattractant protein-1 (MCP-1) in Th1 (mycobacterial) and Th2 (schistosomal) antigeninduced granuloma formation: relationship to local inflammation, Th cell expression, and IL-12 production. J Immunol 157:46024608 .

Chensue SW, Warmington K, Ruth JH, Kunkel SL. 1997a. Effect of slow release IL-12 and IL-10 on inflammation,local macrophage function and the regional lymphoid response during mycobacterial (Th1) and schistosomal (Th2) antigen-elicited pulmonary granuloma formation. Inflamm Res 46:86-92.

Chensue SW, Warmington KS, Ruth JH, Lukacs N, Kunkel SL. 1997b. Mycobacterial and schistosomal antigen-elicited granuloma formation in IFN-gamma and IL-4 knockout mice: analysis of local and regional cytokine and chemokine networks. J Immunol 159: 3565-3573.

Chensue SW, Warmington KS, Allenspach EJ, Lu B, Gerard C, Kunkel SL, Lukacs NW. 1999. Differential expression and crossregulatory function of RANTES during mycobacterioal (type 1) and schistosomal (type 2) antigen-elicited granulomatous inflammation. J Immunol 163:165-173.

Colantonio L, Iellem A, Clissi B, Pardi R, Rogge L, Sinigaglia F, D'Ambrosio D. 1999. Upregulation of integrin alpha6/beta1 and chemokine receptor CCR1 by interleukin-12 promotes the migration of human type 1 helper T cells. Blood 94:2981-2989.

Condos R, Rom WN, Weiden M. 2000. Lung-specific immune response in tuberculosis. Int $\mathrm{J}$ Tuberc Lung Dis 4:S11-17.

Constant SL, Bottomly K. 1997. Induction of Th1 and Th2 CD4+ T cell responses: the alternative approaches. Annu Rev Immunol 15: $297-322$.

Cyster JG. 1999. Chemokines and cell migration in secondary lymphoid organs. Science 286:2098-2102.

D’Ambrosio D, Iellem A, Bonecchi R, Mazzeo D, Sozzani S, Mantovani A, Sinigaglia F. 1998. Selective up-regulation of chemokine receptors CCR 4 and CCR8 upon activation of polarized human type 2 Th cells. J Immunol 161:5111-5115.

D'Ambrosio D, Iellem A, Colantonio L, Clissi B, Pardi R, Sinigaglia F. 2000. Localization of Th-cell subsets in inflammation: differential thresholds for extravasation of Th1 and Th2 cells. Immunol Today $21: 183-186$.

Dieu MC, Vanbervliet B, Vicari A, Bridon JM, Oldham E, Ait-Yahia S, Briere F, Zlotnik A, Lebecque S, Caux C. 1998. Selective recruitment of immature and mature dendritic cells by distinct chemokines expressed in different anatomic sites. J Exp Med 188:373386.

Fallon PG, Richardson EJ, McKenzie GJ, McKenzie AN. 2000. Schistosome infection of transgenic mice defines distinct and contrasting pathogenic roles for IL-4 and IL-13: IL-13 is a profibrotic agent. J Immunol 164:2585-2591.

Forster R, Mattis AE, Kremmer E, Wolf E, Brem G, Lipp M. 1996. A putative chemokine receptor, BLR1, directs B cell migration to defined lymphoid organs and specific anatomic compartments of the spleen. Cell 87:1037-1047.

Forster R, Schubel A, Breitfeld D, Kremmer E, Renner-Muller I, Wolf E, Lipp M. 1999. CCR7 coordinates the primary immune response by establishing functional microenvironments in secondary lymphoid organs. Cell 99:23-33.

Galli G, Chantry D, Annunziato F, Romagnani P, Cosmi L, Lazzeri E, Manetti R, Maggi E, Gray PW, Romagnani S. 2000. Macrophagederived chemokine production by activated human $\mathrm{T}$ cells in vitro and in vivo: preferential association with the production of type 2 cytokines. Eur J Immunol 30:204-210.

Gao JL, Wynn TA, Chang Y, Lee EJ, Broxmeyer HE, Cooper S, Tiffany HL, Westphal H, Kwon-Chung J, Murphy PM. 1997. Impaired host defense, hematopoiesis, granulomatous inflammation 
and type 1-type 2 cytokine balance in mice lacking CC chemokine receptor 1. J Exp Med 185:1959-1968.

Gharaee-Kermani M, Denholm EM, Phan SH. 1996. Costimulation of fibroblast collagen and transforming growth factor beta1 gene expression by monocyte chemoattractant protein-1 via specific receptors. J Biol Chem 271:17779-17784.

Guan P, Burghes AH, Cunningham A, Lira P, Brissette WH, Neote K, McColl SR. 1999. Genomic organization and biological characterization of the novel human CC chemokine DC-CK-1/PARC/MIP-4/ SCYA18. Genomics 56:296-302.

Gunn MD, Kyuwa S, Tam C, Kakiuchi T, Matsuzawa A, Williams LT, Nakano H. 1999. Mice lacking expression of secondary lymphoid organ chemokine have defects in lymphocyte homing and dendritic cell localization. J Exp Med 189:451-460.

Henderson GS, Conary JT, Summar M, McCurley TL, Colley DG. 1991. In vivo molecular analysis of lymphokines involved in the murine immune response during Schistosoma mansoni infection. I. IL-4 mRNA, not IL-2 mRNA, is abundant in the granulomatous livers, mesenteric lymph nodes, and spleens of infected mice. J Immunol 147:992-997.

Henderson GS, Lu X, McCurley TL, Colley DG. 1992. In vivo molecular analysis of lymphokines involved in the murine immune response during Schistosoma mansoni infection. II. Quantification of IL-4 mRNA, IFN-gamma mRNA, and IL-2 mRNA levels in the granulomatous livers, mesenteric lymph nodes, and spleens during the course of modulation. J Immunol 148:2261-2269.

Hogaboam CM, Bone-Larson CL, Lipinski S, Lukacs NW, Chensue SW, Strieter RM, Kunkel SL. 1999a. Differential monocyte chemoattractant protein-1 and chemokine receptor 2 expression by murine lung fibroblasts derived from Th1- and Th2-type pulmonary granuloma models. J Immunol 163:2193-2201.

Hogaboam CM, Bone-Larson CL, Steinhauser ML, Lukacs NW, Colletti LM, Simpson KJ, Strieter RM, Kunkel SL. 1999b. Novel CXCR2-dependent liver regenerative qualities of ELR-containing CXC chemokines. Faseb J 13:1565-1574.

Hogaboam CM, Chensue SW, Kunkel SL. 1999c. The role of CC chemokines in Th1- and Th2-type pulmonary inflammation models. In: Hebert CA, editor. Chemokines in disease. Totowa, NJ: Humana Press. p 139-149.

Hogaboam CM, Lukacs NW, Chensue SW, Strieter RM, Kunkel SL. 1998. Monocyte chemoattractant protein-1 synthesis by murine lung fibroblasts modulates CD4+ $\mathrm{T}$ cell activation. J Immunol 160:4606-4614.

Imai T, Nagira M, Takagi S, Kakizaki M, Nishimura M, Wang J, Gray PW, Matsushima K, Yoshie O. 1999. Selective recruitment of CCR4bearing Th2 cells toward antigen-presenting cells by the CC chemokines thymus and activation-regulated chemokine and macrophage-derived chemokine. Int Immunol 11:81-88.

Johnston B, Burns AR, Suematsu M, Issekutz TB, Woodman RC, Kubes P. 1999. Chronic inflammation upregulates chemokine receptors and induces neutrophil migration to monocyte chemoattractant protein-1. J Clin Invest 103:1269-1276.

Karpus WJ, Lukacs NW, Kennedy KJ, Smith WAS, Hurst SD, Barrett TA. 1997. Differential CC chemokine-induced enhancement of T helper cell cytokine production. J Immunol 158:4129-4136.

Karpus WJ, Kennedy KJ, Kunkel SL, Lukacs NW. 1998. Monocyte chemotactic protein 1 regulates oral tolerance induction by inhibition of T helper cell 1-related cytokines. J Exp Med 187:733-741.

Kay AB. 1998. Role of T cells in asthma. Chem Immunol 71:178-191.

Keane MP, Strieter RM. 1999. The role of CXC chemokines in the regulation of angiogenesis. Chem Immunol 72:86-101.

Kon OM, Kay AB. 1999. T cells and chronic asthma. Int Arch Allergy Immunol 118:133-135.

Kunkel SL, Lukacs NW, Strieter RM, Chensue SW. 1996. Th1 and Th2 responses regulate experimental lung granuloma development. Sarcoid Vasc Diffuse Lung Dis 13:120-128.

Kunkel SL, Lukacs NW, Strieter RM, Chensue SW. 1998. Animal models of granulomatous inflammation. Semin Respir Infect 13: $221-228$

Le Gros G, Erb K, Harris N, Holloway J, McCoy K, Ronchese F. 1998. Immunoregulatory networks in asthma. Clin Exp Allergy 28:92-96 [discussion 117-118].

Lloyd CM, Delaney T, Nguyen T, Tian J, Martinez AC, Coyle AJ, Gutierrez-Ramos JC. 2000. CC chemokine receptor (CCR)3/eotaxin is followed by CCR4/monocyte-derived chemokine in mediating pulmonary $\mathrm{T}$ helper lymphocyte type 2 recruitment after serial antigen challenge in vivo. J Exp Med 191:265-274

Lu B, Rutledge BJ, Gu L, Fiorillo J, Lukacs NW, Kunkel SL, North R, Gerard C, Rollins BJ. 1998. Abnormalities in monocyte recruitment and cytokine expression in monocyte chemoattractant protein 1-deficient mice. J Exp Med 187:601-608.
Ludewig B, Odermatt B, Ochsenbein AF, Zinkernagel RM, Hengartner H. 1999. Role of dendritic cells in the induction and maintenance of autoimmune diseases. Immunol Rev 169:45-54.

Lukacs NW, Addison CL, Gauldie J, Graham F, Simpson K, Strieter RM, Warmington K, Chensue SW, Kunkel SL. 1997a. Transgeneinduced production of IL-4 alters the development and collagen expression of T helper cell 1-type pulmonary granulomas. J Immunol 158:4478-4484.

Lukacs NW, Chensue SW, Karpus WJ, Lincoln P, Keefer C, Strieter RM, Kunkel SL. 1997b. C-C chemokines differentially alter interleukin-4 production from lymphocytes. Am J Pathol 150:1861-1868.

Lukacs NW, Hogaboam C, Campbell E, Kunkel SL. 1999. Chemokines: function, regulation and alteration of inflammatory responses. Chem Immunol 72:102-120.

Mahalingam S, Karupiah G. 1999. Chemokines and chemokine receptors in infectious diseases. Immunol Cell Biol 77:469-475.

Mantovani A, Allavena P, Vecchi A, Sozzani S. 1998. Chemokines and chemokine receptors during activation and deactivation of monocytes and dendritic cells and in amplification of Th1 versus Th2 responses. Int J Clin Lab Res 28:77-82.

Matsukawa A, Hogaboam CM, Lukacs NW, Lincoln PM, Strieter RM, Kunkel SL. 2000a. Endogenous MCP-1 influences systemic cytokine balance in a murine model of acute septic peritonitis. Exp Mol Pathol 68:77-84.

Matsukawa A, Lukacs NW, Standiford TJ, Chensue SW, Kunkel SL. $2000 \mathrm{~b}$. Adenoviral-mediated overexpression of monocyte chemoattractant protein-1 differentially alters the development of Th1 and Th2 type responses in vivo. J Immunol 164:1699-1704.

Moller DR. 1999. Cells and cytokines involved in the pathogenesis of sarcoidosis. Sarcoid Vasc Diffuse Lung Dis 16:24-31.

Moser B. 1998. Human chemokines: role in lymphocyte trafficking. Sci Prog 81:299-313.

Murphy PM. 1997. Neutrophil receptors for interleukin-8 and related CXC chemokines. Semin Hematol 34:311-318.

Ngo VN, Tang HL, Cyster JG. 1998. Epstein-Barr virus-induced molecule 1 ligand chemokine is expressed by dendritic cells in lymphoid tissues and strongly attracts naive T cells and activated B cells. J Exp Med 188:181-191.

Penton-Rol G, Polentarutti N, Luini W, Borsatti A, Mancinelli R, Sica A, Sozzani S, Mantovani A. 1998. Selective inhibition of expression of the chemokine receptor CCR2 in human monocytes by IFNgamma. J Immunol 160:3869-3873.

Richmond A, Luan J, Du J, Haghnegahdar H. 1999. The role of $\mathrm{ELR}^{+}$-CXC chemokines in wound healing and melanoma biology. In: Hebert CA, editor. Chemokines in disease. Totowa, NJ: Humana Pres Inc. p 191-214.

Roitt I, Brostoff J, Male D. 1998. Immunology. London: Mosby.

Romagnani S. 1997. The Th1/Th2 paradigm. Immunol Today 18:263266.

Rossi DL, Hurst SD, Xu Y, Wang W, Menon S, Coffman RL, Zlotnik A. 1999. Lungkine, a novel CXC chemokine, specifically expressed by lung bronchoepithelial cells. J Immunol 162:5490-5497.

Rothenberg ME. 2000. Chemokines in allergic disease. New York: Marcel Dekker.

Rothenberg ME, Zimmermann N, Mishra A, Brandt E, Birkenberger LA, Hogan SP, Foster PS. 1999. Chemokines and chemokine receptors: their role in allergic airway disease. J Clin Immunol $19: 250-265$.

Roussos C. 1995. The Thorax. Lung biology in health and disease, 2nd ed. New York: Marcel Dekker.

Ruth JH, Lukacs NW, Warmington KS, Polak TJ, Burdick M, Kunkel SL, Strieter RM, Chensue SW. 1998. Expression and participation of eotaxin during mycobacterial (type 1) and schistosomal (type 2) antigen-elicited granuloma formation. J Immunol 161:4276-4282.

Rutledge BJ, Rayburn H, Rosenberg R, North RJ, Gladue RP, Corless CL, Rollins BJ. 1995. High level monocyte chemoattractant protein-1 expression in transgenic mice increases their susceptibility to intracellular pathogens. J Immunol 155:4838-4843.

Saeki H, Moore AM, Brown MJ, Hwang ST. 1999. Cutting edge: secondary lymphoid-tissue chemokine (SLC) and CC chemokine receptor 7 (CCR7) participate in the emigration pathway of mature dendritic cells from the skin to regional lymph nodes. J Immunol 162:2472-2475.

Sallusto F, Lanzavecchia A, Mackay CR. 1998a. Chemokines and chemokine receptors in T-cell priming and Th1/Th2-mediated responses. Immunol Today 19:568-574.

Sallusto F, Lenig D, Mackay CR, Lanzavecchia A. 1998b. Flexible programs of chemokine receptor expression on human polarized $\mathrm{T}$ helper 1 and 2 lymphocytes. J Exp Med 187:875-883.

Sallusto F, Kremmer E, Palermo B, Hoy A, Ponath P, Qin S, Forster R, Lipp M, Lanzavecchia A. 1999. Switch in chemokine receptor 
expression upon TCR stimulation reveals novel homing potential for recently activated T cells. Eur J Immunol 29:2037-2045.

Soto H, Wang W, Strieter RM, Copeland NG, Gilbert DJ, Jenkins NA, Hedrick J, Zlotnik A. 1998. The CC chemokine 6Ckine binds the CXC chemokine receptor CXCR3. Proc Natl Acad Sci USA 95:82058210

Syrbe U, Siveke J, Hamann A. 1999. Th1/Th2 subsets: distinct differences in homing and chemokine receptor expression? Springer Semin Immunopathol 21:263-285.

Taub DD, Ortaldo JR, Turcovski-Corrales SM, Key ML, Longo DL, Murphy WJ. 1996a. Beta chemokines costimulate lymphocyte cytolysis, proliferation, and lymphokine production. J Leukoc Biol 59:81-89.

Taub DD, Turcovski-Corrales SM, Key ML, Longo DL, Murphy WJ. 1996b. Chemokines and T lymphocyte activation: I. Beta chemokines costimulate human $\mathrm{T}$ lymphocyte activation in vitro. J Immunol 156:2095-2103.

Vestergaard C, Yoneyama H, Murai M, Nakamura K, Tamaki K, Terashima Y, Imai T, Yoshie O, Irimura T, Mizutani H, Matsushima K. 1999. Overproduction of Th2-specific chemokines in NC/ Nga mice exhibiting atopic dermatitis-like lesions. J Clin Invest 104:1097-1105.

Walker LS, Gulbranson-Judge A, Flynn S, Brocker T, Raykundalia C, Goodall M, Forster R, Lipp M, Lane P. 1999. Compromised OX40 function in CD28-deficient mice is linked with failure to develop CXC chemokine receptor 5-positive CD4 cells and germinal centers. J Exp Med 190:1115-1122.
Warmington KS, Boring L, Ruth JH, Sonstein J, Hogaboam CM, Curtis JL, Kunkel SL, Charo IR, Chensue SW. 1999. Effect of C-C chemokine receptor 2 (CCR2) knockout on type-2 (schistosomal antigen-elicited) pulmonary granuloma formation: analysis of cellular recruitment and cytokine responses. Am J Pathol 154:14071416.

Yoneyama H, Harada A, Imai T, Baba M, Yoshie O, Zhang Y, Higashi H, Murai M, Asakura H, Matsushima K. 1998. Pivotal role of TARC, a CC chemokine, in bacteria-induced fulminant hepatic failure in mice. J Clin Invest 102:1933-1941.

Yoshimura T, Matsushima K, Tanaka S, Robinson EA, Appella E, Oppenheim JJ, Leonard EJ. 1987. Purification of a human monocyte-derived neutrophil chemotactic factor that has peptide sequence similarity to other host defense cytokines. Proc Natl Acad Sci USA 84:9233-9237.

Yoshimura T, Yuhki N, Moore SK, Appella E, Lerman MI, Leonard EJ. 1989. Human monocyte chemoattractant protein-1 (MCP-1). Full-length cDNA cloning, expression in mitogen-stimulated blood mononuclear leukocytes, and sequence similarity to mouse competence gene JE. FEBS Lett 244:487-493.

Zisman DA, Kunkel SL, Strieter RM, Tsai WC, Bucknell K, Wilkowski J, Standiford TJ. 1997. MCP-1 protects mice in lethal endotoxemia. J Clin Invest 99:2832-2836.

Zlotnik A, Morales J, Hedrick JA. 1999. Recent advances in chemokines and chemokine receptors. Crit Rev Immunol 19:1-47.

Zlotnik A, Yoshie O. 2000. Chemokines: a new classification system and their role in immunity. Immunity 12:121-127. 